To appear in I. Angelelli y M. Cerezo, eds., Studies on the History of Logic. Proceedings of the III Symposium on History of Logic, Gruyter, Berlin, 1996, 281-294.

\title{
SCHOLARSHIP ON THE RELATIONS BETWEEN LUDWIG WITTGENSTEIN AND CHARLES S. PEIRCE*
}

Jaime NUBIOLA

University of Navarra, Spain

It is now over thirty years since Richard Rorty pointed out the similarities between Wittgenstein's Philosophical Investigations (1953) and the philosophical framework of Charles S. Peirce (1839-1914), the American logician who was the founder of pragmatism. The view put forward by Rorty is that Peirce had envisaged and repudiated positivist empiricism fifty years earlier, and had developed a set of insights and a philosophical mood very similar to those of contemporary philosophers working under the influence of the later Wittgenstein. The affinity between Peirce's philosophy and the more recent tendency born of the rejection of the Tractatus and the positivism of the Vienna Circle, gave rise to an expectation that the study of Peircean pragmatism and the writings of the later Wittgenstein in ever closer comparison would shed increasing light on both philosophers' work (Rorty 1961).

Similarly, on a more recent occasion Christopher Hookway emphasised that the best approach for understanding Peirce is to see him as an analytic philosopher avant la lettre. It is well known that Karl-Otto Apel identified Peirce's thought as the milestone in the process of semiotic transformation from transcendental philosophy into analytic philosophy (Apel 1981). Many of the distinctive features of analytic philosophy are already present in Peirce, and many of the problems which concerned Peirce most are central to contemporary philosophical debate. In this sense, the best way to approach Peirce is by assuming that he was attempting something similar to present-day analytic philosophy of language, as both his goals and his basic ideas have much in common with the latter (Hookway 1985: 141).

In spite of this proximity, academic research focusing on the thought of Wittgenstein and Peirce has almost always tended to handle these two writers quite separately. It has sometimes been said that the notoriously pragmatist flavour of Philosophical Investigations was due to the influence of Frank P. Ramsey: according to this interpretation, it was the young Ramsey who, by awakening Wittgenstein from the dogmatic slumber of the Tractatus, guided Wittgenstein's reflections in a pragmatic direction (Passmore 1957: 425). However, little precise information is available as to the actual way in which American pragmatist philosophy might have helped mould the thought of the later Wittgenstein.

The writings of Ludwig Wittgenstein do not contain a single mention of Charles S. Peirce, but it might well be wrong to draw any conclusions from this, as Wittgenstein's scant regard for the academic practice of acknowledging intellectual property is notorious. In both the preface to the Tractatus and that of the Philosophical Investigations, Wittgenstein apologises for not using the traditional bibliographical apparatus in work of an academic nature:

"I give no sources, because it is indifferent to me whether what I have thought has already been thought before me by another" (1922: 27). "For more than one reason what I publish here will have points of contact with what another people are writing today. - If my remarks do not bear a stamp which marks them as mine, - I do not wish to lay any further claim to them as my property" (1988: 17).

In fact, neither Wittgenstein's pupils nor his colleagues recall hearing him mention Charles S. Peirce (Hardwick 1979: 30, n.5). By contrast to this, towards the end of his life Wittgenstein took a

\footnotetext{
* I wish to thank Christian J.W. Kloesel and Christopher Hookway for their bibliographical suggestions, and Jorge V. Arregui and Eduardo Guerrero for their comments on the first draft of this paper. Also I am indebted to Ruth Breeze for her careful English translation.
} 
considerable interest in William James, and read his work. In his lectures, Wittgenstein refers to him fairly often in order to illustrate the confusions to which the mind is subject in philosophy, and for a while William James's The Principles of Psychology was the only book Wittgenstein kept in his room (Thayer 1968: 313).

In 1968 H.S. Thayer gave voice to a hope that a historian would one day clear up the question of the relationship between American pragmatism and Wittgenstein's thought. Twenty-five years later, however, the relations between Wittgenstein and Peirce are still not wholly explained, as we lack any proof of a direct link. There are some connections, in the form of people who had some kind of link with Peirce and were in direct contact with Wittgenstein; but as Hardwick indicated (1979: 26), the missing link probably lies in Wittgenstein's conversations with Ramsey in the last two years of the latter's life. "What Wittgenstein owed to Peirce is not easy to say," Deledalle writes (1990: 134), but the suggestion that the pragmatic vein running through the later Wittgenstein is of a Peircean nature would seem plausible (Hardwick 1979: 25).

In concrete, the aim of my paper is to describe in some detail not so much the overlap between Peirce and the later Wittgenstein, which has been discussed by various scholars (Mullin 1961; Rorty 1961; Ransdell 1976; Bambrough 1981; Haack 1982; Gorlée 1989; Hookway 1990; Fabbrichesi 1993), as the concrete lines along which academic research has established the historical connection between the two philosophers. To this end, now that I have outlined the background to my paper, I propose to divide my discussion into three parts of different lengths. First I shall summarise the information available about Peirce's reception in British philosophy in the first thirty years of this century, with particular reference to Lady Welby, Charles Ogden and Bertrand Russell. I shall then report in some detail on Frank Ramsey's role as the link between Peirce and Wittgenstein. Finally, by way of conclusion, I shall provide a brief overall evaluation of the academic research into the relations between these two thinkers.

\section{Peirce's reception in British philosophy: Lady Welby, Ogden and Russell.}

Victoria Welby was Peirce's main intellectual contact in the last years of his life, when he was living the life of an impoverished hermit in Milford, Pennsylvania. Lady Welby was a leading figure in British semiotics at the turn of the century. She had no formal university education, but was an enthusiast for the study of signification, and had invented a new science of language, which she called "Significs". She contributed to Mind, and knew personally or corresponded with many of the intellectuals of the day.

The epistolary relationship between Peirce and Lady Welby, which was to last nine years, started in 1903, when she sent him a copy of her book What is Meaning?, which Peirce reviewed enthusiastically together with Russell's The Principles of Mathematics. He devoted only the first paragraph of his review to Russell's book, reserving two pages for that of Lady Welby. His review began with the statement "Two really important works on logic are these; or, at any rate, they deserve to become so" (Hardwick 1977: 157).

Lady Welby had a certain knowledge of pragmatic philosophy. She had corresponded with William James, the British pragmatist F.C.S. Schiller, and the Italian pragmatists Vailati and Calderoni (Hardwick 1977: xxix), and was to be responsible for circulating Peirce's ideas in Britain. With this in mind, she sent copies of Peirce's letter of 12 October 1904, in which he had sketched out his complete theory of signs, to many friends and colleagues, including Russell, Cook Wilson and Ogden. In particular, Lady Welby had fixed upon Ogden in Cambridge as being a student of Peirce (Lady Welby's letter, 2.5.1911; Hardwick 1977: 138-139), and she passed on to him the papers concerning existential graphs which Peirce had sent her, which she was unable to understand. One of Lady Welby's aspirations was to bring about a meeting between Peirce and Russell, and in fact she acted as an intermediary between them, though to no avail (Hardwick 1977: xxx). Many years later, Russell was to acknowledge that Lady Welby and F.C.S. Schiller had set a precedent for his own philosophical development towards the problem of the relations between language and facts, as in the Principia Mathematica he had taken language to be something transparent which could therefore be used without itself being the object of attention (Russell 1959: 11).

In 1923, Charles Ogden, the former pupil of Lady Welby, joined with I. A. Richards to publish the book The Meaning of Meaning, which was to have a certain importance in British philosophy. In this book, which is subtitled "A Study of the Influence of Language upon Thought and of the Science of Symbolism", Ogden included an appendix which is an introduction to Peirce based on extracts from three of his letters to Lady Welby (12.10.1904, 14.12.1908 and 14.3.1909) and two articles 
published in The Monist in 1905 and 1906 (Ogden 1923: 432-444). In March 1923, Ogden, who had translated and published the Tractatus with the aid of Frank P. Ramsey, who was then a student (Wittgenstein 1973: 8), sent a copy of The Meaning of Meaning to Wittgenstein, who was working as a country schoolmaster in Puchberg. In Wittgenstein's letter acknowledging receipt of the book, he explained to Ogden that he had been suffering from some nervous complaint for a month, and "this is the reason why I have not yet been able to read your book thoroughly" (Wittgenstein 1973: 69).

As Ogden believed that his book went some way towards providing a causal solution to the problem of meaning outlined in the Tractatus, Wittgenstein felt obliged to give an appraisal of the book, and he answered frankly that in his view, Ogden had not entirely grasped the problems which he had tackled in Tractatus (Wittgenstein 1973: 69). In a letter to Russell on 7 April, he went further on the subject of The Meaning of Meaning:

"Is it not a miserable book?! Philosophy is not as easy as that! The worst thing is the introduction of Professor Postgate Litt. D. F. B. A. etc. etc. I have seldom read anything so foolish." (Monk 1991: 214).

This introduction was in fact omitted from later editions. In view of this reaction, Wittgenstein may well not have reached the final pages of The Meaning of Meaning which included the passages from Peirce, but it is also possible that he did indeed read this section and thus had his first exposure to Peirce's thought. In any case, he must have read the highly favourable references to Peirce in the preface, where he figures among the authors whose ideas Ogden and Richards acknowledge, as well as the first page, on which it is stated that Peirce had recognised the importance of the problem of meaning, but had felt that he should forego his ambition to attempt to solve it on the grounds of his advanced years and financial hardship (1923: ix and 1). Even so, Ogden's account is somewhat confusing, focusing as it does especially on classifications, and tends rather to discourage the reader from taking on Peirce directly. Hardwick was able to show that the posture adopted by Ogden and Richards in The Meaning of Meaning was, in the last instance, incompatible with that of Peirce, because even though they defended a triadic relationship between thought, symbol and reference, they did so in a simplistic manner which quite lacks the breadth and subtlety of Peirce's semiotics (1979: 27).

In The Principles of Mathematics § 27 Bertrand Russell acknowledged the importance of Peirce's work on logic, particularly his algebra of diadic relationships. "I have always thought very highly of Dr. Peirce for having introduced such a method," he wrote later to Lady Welby (Hardwick 1977: xxx). In fact, Peirce's modifications to Boole's logic had been known and valued among European logicians and mathematicians in general terms ever since Schröder's extensive discussion of them in his Algebra der Logik. (In the 1898 Cambridge Lectures, published just a few months ago, Peirce remarks lightheartedly that Schröder seemed to have fallen in love with his algebra of diadic relationships. Peirce 1992: 150.) In British philosophical circles, some works of James and Dewey were also known, although they were probably not subjected to careful scrutiny (Thayer 1968: 304-305). At the international philosophy conferences in 1900, 1904 and especially the one held in Heidelberg in 1908, the pragmatist propositions of the American philosophers were the focus of international debate (Geldsetzer 1981).

Up to 1923, however, Russell showed not the slightest interest in Peircean semiotics, despite attempts to bring them together on the part of Lady Welby, who believed that the work of Russell and Peirce confirmed her semantic theories. Years later Russell wrote that

"Peirce himself, like Leibniz, gave to the world only fragments of his system, with the result that he has been very thoroughly misunderstood, not least by those who professed to be his admirers. I am - I confess to my shame- an illustration of the undue neglect from which Peirce has suffered in Europe. I heard of him first from William James when I stayed with that eminent man in Harvard in 1896. But I read nothing of him until 1900, when I had become interested in extending symbolic logic to relations, and learnt from Schröder's Algebra der Logik that Peirce had treated of the subject. Apart from his work on this topic, I had until recently read nothing of him except the volume entitled by its editors Chance, Love and Logic." (Russell 1946: xv).

That anthology, published by Morris Cohen in 1923, had a clear and accurate introduction to the main issues in Peirce's philosophy and distinguished his ideas from James' pragmatism. Alfred J. Ayer stressed the historical interest of this selection, since until then English philosophers had derived their mainly unfavourable ideas of pragmatism from the popular writings of James and Schiller (Ayer 1968: 4). Along this line, Susan Haack has suggested that the root of the uncongeniality between Russell 
and pragmatist philosophy can perhaps be traced back, at least in part, to Russell's personal hostility towards F. C. S. Schiller as a representative pragmatist. Although inWisdom of the West Russell was to write that Peirce had been beyond doubt "one of the most original minds of the end of the later nineteenth century, and certainly the greatest American thinker ever" (1959: 267), these quotations serve to indicate that Russell's acquaintance with Peircean thought was probably very limited and, in any case, it long postdates the end of his relations with Wittgenstein.

\section{Frank Ramsey as link}

The relationship between Frank P. Ramsey (1903-30) and Wittgenstein is well known, and Wittgenstein duly acknowledges Ramsey's influence in the preface to Philosophical Investigations:

"I was helped to realize these mistakes - to a degree which I myself am hardly able to estimate - by the criticism which my ideas encountered from Frank Ramsey, with whom I discussed them in innumerable conversations during the last two years of his life" (1953: viii).

Ramsey's connection with Peirce's writing and ideas proves to have been closer than that of Ogden, and is well documented. Ramsey had become aware of Peirce's logic through Russell, Schröder and, perhaps, the detailed outline provided by C. I. Lewis in A Survey of Symbolic Logic (1918). Thayer suggests that Ramsey may have heard about Peirce's interest in the theory of signs and meaning from Russell (1968: 305), but it was certainly Ogden, whom he had helped on the translation of the Tractatus at the age of eighteen, who was his main source of information about Peirce's work.

\subsection{References to Peirce in Ramsey's writing}

Below is a brief outline of the evidence for Ramsey's knowledge of Peirce's work:

1923. In Ramsey's long and perceptive review of the Tractatus in Mind, the only person quoted apart from Russell and Wittgenstein himself was Charles S. Peirce. Ramsey pointed out (1923: 468) that the use of "proposition" in Tractatus, unlike Russell's use of the word in The Principles of Mathematics, was ambiguous, and that this ambiguity could have been avoided had Wittgenstein introduced Peirce's distinction between "type" and "token". We know that Ramsey had already written this review before visiting Wittgenstein in Puchberg, but it is not known whether they talked about this observation in the visits of 1923 and 1924 (Thayer 1968: 310).

1924. In Ramsey's rather critical review of The Meaning of Meaning by C. K. Ogden and I. A. Richards, published the next year in Mind, he emphasises that "the excellent appendix on Peirce deserves especial mention" (1924: 109). Ramsey was greatly impressed by the extracts from the letters to Lady Welby (Houser and Kloesel 1992: xxii). The Meaning of Meaning (1923: 280-281) also includes an extract from Peirce's 1906 article in The Monist, in which he explains the distinction between "type" and "token".

1926. In "Truth and Probability", read in part at the Moral Sciences Club in Cambridge, then compiled posthumously in his Philosophical Papers (1990: 52-94), Ramsey quotes Peirce on three occasions (52, 81-2, 90n), and explicitly takes Peirce as the basis for his final paragraphs on the pragmatic justification for the intellectual habits of inference, observation and memory.

Ramsey maintains that induction is a habit, and that as such it requires no logical justification, as there can be no justification which does not proceed by induction.

"Induction is such a useful habit, and so to adopt it is reasonable. All that philosophy can do is to analyse it, determine the degree of its utility, and find on what characteristics of nature this depends." "It is a human logic", and "its business is to consider methods of thought, and discover what degree of confidence should be placed in them" (1900: 94).

That is, Ramsey maintains that induction has no formal justification, but this does not make its use any the less reasonable, as its reasonableness is pragmatic (Thayer 1968: 310).

In Ramsey's short intellectual biography, this study marked "the beginning of something new", as Sahlin has recently shown (1990: 67, 102), as it "is imbued with the pragmatism of Peirce". It seems clear that he owed this pragmatic orientation to his reading of Peirce (Hookway 1980: 91). Ramsey quotes Peirce from the anthology Chance, Love and Logic . 
1927. In "Facts and Propositions" Ramsey does not quote Peirce, but in the final paragraphs, after underlining his great debt to Wittgenstein, "from whom my view of logic is derived", he adds:

"Everything that I have said is due to him, except the parts which have a pragmatist tendency, which seem to me to be needed in order to fill up a gap in his system" (1990: 51).

This recognition of a gap in the Tractatus which could be filled satisfactorily by pragmatism lends support to the suggestion that Ramsey might have tried, in the course of his conversations with Wittgenstein over the subsequent two years, to explain both the problem and the pragmatist solution which he had drafted. Yet the point should be made that in this passage, much to the surprise of readers today, Ramsey attributes his pragmatism to Russell, not Peirce:

"My pragmatism is derived from Mr Russell; and is, of course, very vague and undeveloped. The essence of pragmatism I take to be this, that the meaning of a sentence is to be defined by reference to the actions to which asserting it would lead, or, more vaguely still, by its possible causes and effects" (1990: 51).

The reference to Russell as the source of Ramsey's pragmatism is certainly somewhat disconcerting, since Russell was not a pragmatist, nor was he ever considered one. Russell knew the works of William James, and some of Peirce's writing, but in his publications he had never defended a pragmatist position. By pushing the literal meaning of Ramsey's words, Hardwick interprets it as a statement to the effect that Russell had introduced him to pragmatism, and in fact the superficial description of pragmatism which he puts forward is a paraphrase of Peirce (1979: 28).

1929. Lastly, Ramsey explicitly mentions the Peircean notion of truth as the final opinion which everyone would reach in the long run, in "General Propositions and Causality", which was among the work published posthumously (1990: 161).

\subsection{The conversations between Ramsey and Wittgenstein in 1929}

Wittgenstein returned to Cambridge in January 1929, and until Ramsey's death in January 1930, Ramsey was not only his most valued counterpart in philosophical conversations, but also his closest friend. In these discussions, to borrow the interpretation put forward by Monk (1990: 260), Ramsey was a mathematician struggling with the problems of the bases of mathematics, while Wittgenstein's interests lay rather in extracting the philosophical root from which the confusion about mathematics grew.

We do not know exactly what was said in these conversations, but one of Ramsey's last essays, entitled "Philosophy", is of particular interest in this context, as it seems to reflect his fundamental disagreement with Wittgenstein. As Hardwick suggested (1979: 28), "Philosophy" could be read as the most faithful summary available of those "innumerable conversations" to which Wittgenstein acknowledged his indebtedness in his preface to Philosophical Investigations quoted above.

In fact, his later rejection of some of the theses of Tractatus is in keeping with the criticisms which Ramsey sets out here. In "Philosophy", which scarcely amounts to seven pages, Ramsey expressly touches upon many of the issues which would later be extensively worked over by Wittgenstein in The Blue and Brown Books and the Philosophical Investigations: the nature and end of philosophy, what a definition is, what it is to understand a word and recognise whether or not a definition is correct, vagueness, the notion of meaning as an explanation of use and essential key to truth, the analysis of complex sensations for which we have no name, the appeal to our own mental states or those of others, and so on. As everyone knows, by contrast to the views held in the Tractatus on the figurative character of language, the meaning of which rests on its logical structure, the later Wittgenstein advocated a much richer analysis of language games, of human linguistic conduct in its colourful wealth and variety.

The two explicit criticisms of Wittgenstein which Ramsey put into writing in "Philosophy" are perceptive and well-aimed. The first is the absurd posture of the Tractatus, which condemns philosophy to being nonsense, then goes on to pretend "that it is important nonsense!" (Ramsey 1990: 1). The second, which almost closes Ramsey's note, runs as follows: 
"The chief danger to our philosophy, apart from laziness and woolliness, is scholasticism, the essence of which is treating what is vague as if it were precise and trying to fit it into an exact logical category. A typical piece of scholasticism is Wittgenstein's view that all our everyday propositions are completely in order and that it is impossible to think illogically."

Ramsey's response to this mirrors the reply which the later Wittgenstein might have given:

"This last is like saying that it is impossible to break the rules of bridge because if you break them you are not playing bridge but (...) not-bridge" (Ramsey 1990: 7).

Twenty years later, in Wittgenstein's last notebooks, published by Anscombe and von Wright under the title On Certainty, the subjects whose absence Ramsey had noted appear at every turn: the basis for common sense beliefs, the justification for induction, the habits of memory, what is reasonable, and so on. As Bambrough has suggested, when in paragraph 422 of On Certainty Wittgenstein comes close to calling himself a pragmatist, what he has in mind is the practical dimension of thought. Peirce's habits and Wittgenstein's language games turn out to be alternative expressions for a common strategy of resisting the abstract theorising of much traditional philosophy (Bambrough 1981: 266). Furthermore, On Certainty can be understood as a defence of critical Peircean commonsensism as against Moore's theory of common sense.

\section{Critical survey of academic research into the relations between Wittgenstein and Peirce}

The oldest reference I have been able to find to the possible influence of Peirce on the thought of the later Wittgenstein dates from 1961. This is a conjecture by the Australian scholar Gasking, in a paper given at the University of Illinois in the spring of that year. Albert Mullin contrasted it with a personal communication from Bertrand Russell saying that he doubted that Peirce could have had any influence on Wittgenstein. Mullin himself concluded not only that it was improbable that one thinker should have influenced the other, on the grounds of their utterly different philosophical styles, but also that their thought is complementary rather than similar (1961: 4-5, i).

In the years that followed, Thayer (1968: 304-313), Hardwick (1977b: xxxi and 1979) and Deledalle (1981) defended the thesis that Ramsey had brought Peirce's ideas to Wittgenstein's attention. This would shed light on, though not entirely explain, the clearly pragmatic aspects of the later Wittgenstein (Schmitz 1985: clii-cliii). Along these lines, Hardwick wrote in 1979 that the importance of Peirce's influence on Wittgenstein through Ramsey had not been fully explored, and particularly emphasised that

"what is needed is a careful study of the themes common to Peirce and Wittgenstein. Such a study would provide a context of interpretation which would add an important dimension to the understanding of Wittgenstein's later work" (1979: 29).

In the last few years some work has been done in this direction, despite the obstacles posed by the fact that Peirce and Wittgenstein are the focus of two very different academic communities between which there is little communication.

In the face of the striking disparity between the two philosophers as far as their attitudes to science were concerned, Joseph Ransdell highlighted the philosophical tradition or the systematic character of their thought. He found "a fundamental point of agreement in their philosophies" which could be described as two versions (Wittgenstein's being the more sceptical, that of Peirce the more optimistic) of a common conception of human reason and language, in which these are essentially understood not as the private property of individuals, but rather as thought exercised communally (Ransdell 1976: 405, 431).

In 1981, Ingemund Gullvåg made great play of the similarities between Wittgenstein and Peirce to draw attention to "the possibility that the writings of Peirce influenced Wittgenstein indirectly, through Ramsey, and that they may, after Ramsey's death, have influenced him directly" (1981: 83). 
In the same year, Renford Bambrough pointed out the broad overlap between the two philosophers. When Wittgenstein recalls in paragraph 81 of Philosophical Investigations that "F.P. Ramsey once emphasised in conversation with me that logic was a 'normative science"', the Peircean scholar cannot help thinking that Ramsey was repeating Peirce's motto, even though this expression was not original to Peirce, and the idea is to be found in other authors who do not use this expression. This impression is reinforced when one goes on to hear in the Investigations many echoes of ideas, expressions, analogies and comparisons which are now well known thanks to the eight volumes of Peirce's Collected Papers (Bambrough 1981: 263-264).

In 1985, Christopher Hookway cast some light on the question of the analysis of vagueness and indeterminacy. Following in the footsteps of Rorty 1961 and Fairbanks 1964, Hookway was able to show that Peirce, Ramsey and the later Wittgenstein not only agreed that the vagueness and indeterminacy of the meaning of predicates is benign and tolerable, but all three are to be found defending vagueness, which "is, rather, a virtue, —-something in the absence of which we would simply be unable to say, or think, or do the things we want" (Bell 1990: ix).

In view of all this information, it seems that scholarly research into the relationship between Wittgenstein and Peirce can scarcely yield any new facts. There is, however, a growing interest in the unified or integrating study of the great currents of thought which have run through the philosophy of our century. In this framework pragmatist philosophy in the Peircean tradition and analytic philosophy, heir to the later Wittgenstein, can be understood as different aspects of an integrated stream of contemporary philosophical reflection. One of the factors which explain the success of analytic philosophy in the United States can be traced back to that pragmatic orientation of American academic philosophy, which takes its main source from Peirce.

Bibliographic references

Apel, Karl-Otto. 1981. Charles S.Peirce. From Pragmatism to Pragmaticism. Amherst: University of Massachusetts Press.

Apel, Karl-Otto. 1985. La transformación de la filosofía. Madrid: Taurus.

Ayer, Alfred J. 1968. The Origins of Pragmatism, San Francisco, CA: Freeman, Cooper

Bambrough, Renford. 1981. Peirce, Wittgenstein, and Systematic Philosophy. Midwest Studies in Philosophy 6: 263273.

Bell, David and Neil Cooper, eds. 1990. The Analytic Tradition. Meaning, Thought and Knowledge. Oxford: Blackwell.

Cohen, Morris R. ed. 1923. Chance, Love and Logic. Philosophical Essays by the Late Charles S. Peirce. New York: Harcourt, Brace.

Deledalle, Gerard. 1990. Victoria Lady Welby and Charles Sanders Peirce: Meaning and Signification. In Essays on Significs, edited by A. Eschbach, 133-49. Amsterdam: John Benjamins.

Fairbanks, M.J. 1964. C.S.Peirce and Logical Atomism. New Scholasticism 38: 178-188.

Fabbrichesi, Rossella. 1993. L'immagine logica in Peirce e in Wittgenstein. In Peirce in Italia, edited by M.A.Bonfantini and A. Martone, 393-398. Naples: Liguori.

Geldsetzer, Lutz. 1981. Bibliography of the International Congresses of Philosophy. Proceedings, 1900-1978. München: Saur.

Gorlée, Dinda L. 1989. Wittgenstein et Peirce: Le jeu de langage. Semiotica 73: 219-231.

Gullvåg, Ingemund. 1981. Wittgenstein and Peirce. In Wittgenstein, Aesthetics and Transcendental Philosophy, edited by K.S.Johannessen y T.Nordenstam, 70-85. Vienna: Hölder-Pichler-Tempsky.

Haack, Robin. 1982. Wittgenstein's Pragmatism. American Philosophical Quarterly 19: 163-171.

Hardwick, Charles S. 1977. Semiotic and Significs: The Correspondence Between Charles S. Peirce and Victoria Lady Welby. Bloomington: Indiana University Press.

Hardwick, Charles S. 1979. Peirce's Influence on Some British Philosophers: A Guess at the Riddle. In Peirce Studies 1: 25-29. Lubbock: Institute for Studies in Pragmaticism. 
Hookway, Christopher. 1980. Inference, Partial Belief and Psychological Laws. In Prospects for Pragmatism. Essays in Memory of F.P.Ramsey, edited by D.H.Mellor, 91-108. Cambridge: Cambridge University Press.

Hookway, Christopher. 1985. Peirce. London: Routledge \& Kegan Paul.

Hookway, Christopher. 1990. Vagueness, Logic and Interpretation. In The Analytic Tradition. Meaning, Thought and Knowledge, edited by D. Bell and N. Cooper, 61-82. Oxford: Blackwell.

Houser, Nathan y Christian Kloesel. 1992. The Essential Peirce. Selected Philosophical Writings. Bloomington: Indiana University Press

Monk, Ray. 1991. Ludwig Wittgenstein. The Duty of Genius. London: Vintage.

Mullin, Albert A. 1961. Philosophical Comments on the Philosophies of Charles S. Peirce and Ludwig Wittgenstein. Urbana, Ill.: Electrical Engineering Research Laboratory, University of Illinois.

Ogden, Charles K. and I.A. Richards. 1923. The Meaning of Meaning. London: Routledge \& Kegan Paul.

Passmore, John. 1957. A Hundred Years of Philosophy. London: Duckworth.

Peirce, Charles S. 1936-58. Collected Papers of Charles Sanders Peirce. Edited by C.Hartshorne, P.Weiss, and A.Burks. Cambridge: Harvard University Press.

Peirce, Charles S. 1992. Reasoning and the Logic of Things. The Cambridge Conferences Lectures of 1898. Edited by K.L.Ketner. Cambridge, MA: Harvard University Press.

Ramsey, Frank P. 1923. Review of Tractatus Logico-Philosophicus. Mind 32: 464-478.

Ramsey, Frank P. 1924. Review of The Meaning of Meaning, Mind 33: 108-109.

Ramsey, Frank P. 1990. Philosophical Papers, edited by D.H. Mellor. Cambridge: Cambridge University Press.

Ransdell, Joseph. 1976. The Pursuit of Wisdom: A History of Philosophy. Santa Barbara, CA: Intelman Books.

Rorty, Richard. 1961. Pragmatism, Categories, and Language. Philosophical Review 70: 197-223.

Russell, Bertrand. 1903. The Principles of Mathematics. Cambridge: Cambridge University Press.

Russell, Bertrand. 1946. Foreword to James Feibleman's An Introduction to Peirce's Philosophy Interpreted as a System, New York: Harper.

Russell, Bertrand. 1959. Wisdom of the West. London: Macdonald.

Russell, Bertrand. 1959. My Philosophical Development. London: Allen \& Unwin.

Sahlin, Nils-Eric. 1990. The Philosophy of F.P.Ramsey. Cambridge: Cambridge University Press.

Schmitz, Walter H. 1985. Victoria Lady Welby's Significs. Introduction to Victoria Welby. Significs and Language: The Articulate Form of Our Expressive and Interpretive Resources. Amsterdam: John Benjamins.

Thayer, H.S. 1968. Meaning and Action: A Critical History of Pragmatism. New York: Bobs-Merrill.

Wittgenstein, Ludwig. 1953. Philosophical Investigations.. Edited by G.E.M.Anscombe and R.Rhees. Oxford: Blackwell.

Wittgenstein, Ludwig. 1973. Letters to C.K.Ogden with Comments on the English Translation of the Tractatus LogicoPhilosophicus. Edited by G.H. von Wright. Oxford: Blackwell.

Wittgenstein, Ludwig. 1922. Tractatus Logico-Philosophicus. London: Routledge \& Kegan Paul

Wittgenstein, Ludwig. 1972. On Certainty, edited by G.E.M. Anscombe and G.H. von Wright. New York: Harper Torchbooks.

Wittgenstein, Ludwig. 1953. Philosophical Investigations. Translated by G.E.M. Anscombe. Oxford: Blackwell. 